24. Офіційний сайт Мегабанк [Електронний ресурс] - Режим доступу: https://www.megabank.ua/.

25. Офіційний сайт Банк Восток [Електронний ресурс] - Режим доступу: https://bankvostok.com.ua/.

26. Офіційний сайт Універсал банк [Електронний ресурс] - Режим доступу: https://www.universalbank.com.ua/.

УДК 123.456:789

JEL classification: M31

Замрій А.М.

ORCID ID: 0000-0001-9480-9713

Капустян В.O.

доктор фіз.-мат. наук, професор

ORCID ID: 0000-0002-5035-809X

Національній технічний університет України «Київський політехнічний інститут імені Ігоря Сікорського»

\title{
МОДЕЛЮВАННЯ ПРОЦЕСУ ТЕХНОЛОГІЧНОГО ПЕРЕОЗБРОСННЯ КИЇВСЬКОГО РЕГІОНУ
}

\section{THE MODELING PROCESS OF TECHNOLOGICAL REARMING OF KYIV REGION}

Київський регіон та Україна в иілому перебувають ще на індустріальній стадіі розвитку, і ї̈ можливості ще не вичерпані. Таким чином, стає нагальним завдання широкого використання передових індустріальних технологій з метою модернізації підприємств. При иьому важливим є підняття науково-технологічного рівня підприємств і галузей, в яких ще зберігаються застарілі технології, досягати їх переходу на рівень вищих індустріальної й постіндустріальної стадії. Технічне переозброєння і реконструкція діючих підприємств, будучи однією з форм розииреного відтворення основних фондів, сприяють перш за все оновленню і якісному вдосконаленню існуючих засобів праці, підвищення ролі технічної оснащеності діючих підприємств, автоматизації та механізації виробництва відповідно до вимог НТП. Найбільший ефект від реконструкиї і технічного переозброєння досягається в тих випадках, коли застосування комплексної механізації $i$ автоматизації виробництвва поєднується з впровадженням принципово нових технологічних процесів. У даній статті розглядається один із варіантів вирішення стратегічної задачі, поставленій у Київському регіоні до 2020 року, а саме стійкого економічного зростання на основі інноваційного розвитку. В основі статті лежить модель переозброєння трисекторної економіки Колємаєва В.А., але без деяких спрощень, які автор використовував для аналітичного розв'язку задачі оптимального керування. Ця модель апробована на показниках Київського регіону за 2010 - 2016 роки. Було знайдено показники виробничої функиії Коба-Дугласа для усіх галузей економіки в регіоні. Засновуючись на отриманих показниках галузі були згруповані у три сектори та сформовано вихідні дані для моделі. Методом послідовного квадратичного програмування було знайдено оптимальне рімення для задачі управління переозброєнням регіону. 

функція.

Ключові слова: технологічне переозброєння, трисекторна економіка, виробнича

Kyiv region and Ukraine as a whole are still at the industrial stage of development and its possibilities are not yet exhausted, then the urgent task of widespread use of advanced industrial technologies in order to modernize enterprises is becoming urgent. At the same time, it is important to raise the scientific and technological level of enterprises and industries, which still have outdated technologies, to achieve their transition to a higher level of industrial and post-industrial stage. Technical re-equipment and reconstruction of existing enterprises, as one of the forms of expanded reproduction of fixed assets, contribute primarily to the updating and qualitative improvement of existing means of labor, increasing the role of technical equipment of existing enterprises, automation and mechanization of production in accordance with the requirements of $S \& T$ development. The greatest effect from the reconstruction and technical re-equipment is achieved in those cases where the application of complex mechanization and automation of production is combined with the introduction of fundamentally new technological processes. This article examines one of the options for solving a strategic task set in the Kyiv region by 2020, namely sustainable economic growth based on innovative development. At the heart of the article is the model of reequipment of the three-sector economy V.A. Kolemayeva. but without some simplifications that the author used for the analytical solution of the problem of optimal control. This model is tested on indicators of the Kiev region for 2010 - 2016 years. The indexes of the Cobb-Douglas production function for all branches of the economy in the region were found. Based on the obtained indicators, all branches were grouped into three sectors and generated input data for the model. The method of successive quadratic programming has found the optimal solution for the task of re-equipment management in the region.

Keywords: technological re-equipment, three-sector economy, production function.

Вступ. У 2014 році було розроблено стратегію розвитку київського регіону. При розробці цієї стратегії був використаний SWOT-аналіз для визначення переваг, недоліків, ризиків та можливостей. В економічній сфері однією 3 головних загроз було виділено зростання рівня зносу засобів виробництва на більшості підприємств. Рівень зносу технологічного устаткування сільськогосподарських підприємств у 2013 році був у межах 7080\%. На підставі зазначеної загрози, в рамках загальної стратегії до 2020 року, була сформована операційна ціль по створенню нових та модернізації існуючих галузей економіки регіону [1]. У звітах про реалізацію регіональної стратегії за 2017 та 2018 роки було відзначено реалізацію 46 інвестиційних проектів, створення 13 нових підприємств, 4 індустріальних парків та модернізацію 3 сільськогосподарських підприємств [2]. Станом на 2017 рік у регіоні налічується 936 великих та середніх підприємств [4]. Враховуючи темпи модернізації та наявну кількість підприємств, логічним буде зазначити, що потреба в модернізації залишиться і після 2020 року. Тому розробка моделі технологічного переозброєння регіону в цілому є актуальною та необхідною.

Постановка завдання. Мета статті полягає у дослідженні та апробації моделі переозброєння трисекторної економіки, виявленні переваг та недоліків 
цієї моделі, формуванні стратегії на основі отриманих результатів моделювання для економіки Київського регіону.

Методологія. У процесі дослідження використано статистичні методи дослідження, метод найменших квадратів для пошуку параметрів виробничої функції, оптимальне керування, метод кінцевих різниць, чисельні методи для мінімізації цільової функції в задачі оптимального керування.

Результати дослідження. Перш ніж перейти до моделювання процесу переозброєння Київського регіону розглянемо такі важливі поняття, як трисекторна економіка та виробнича функція. Першою спробою агрегування різних видів економічної діяльності на сектори умовно можна вважати працю К.Кларка "Умови економічного зростання" (1940р.). Економіка поділялась на три сектори: первинний, вторинний i третинний. Сектором економіки вважається сукупність елементів національної економіки із спільними галузевими, технологічними, організаційно-правовими та іншими властивостями. У роботі Колємаєва В.А.([5]) можна детально ознайомитися 3 трисектороною моделлю економіки

Виробнича функція (надалі в.ф.) - це функція, незалежні змінні якої приймають значення обсягів ресурсів, що витрачаються, а залежна змінна значення обсягів випущеної продукції. Однією з найвідоміших в.ф., яка використовується в макроекономічних дослідженнях, $\epsilon$ модифікована в.ф. Кобба-Дугласа. Детально про неї можна дізнатися у [6]. Як зазначається у [7] до переваг цієї функції можна віднести: нелінійність, динамічність та простоту, а до недоліків: проблему ефекту масштабу, проблему встановлення параметрів в.ф., припущення про повну взаємозамінність виробничих ресурсів.

Знайдемо коефіцієнти еластичності за капіталом, та робочою силою, а також коефіцієнти технічного прогресу для кожного економічного напрямку діяльності у регіоні за даними Держкомстату у Київський області за 2010-2016 роки $[3,4]$.

Як бачимо 3 таблиці 1 , найбільш близькими за коефіцієнтами до неокласичної в.ф. такі напрямки економічної діяльності: промисловість; будівництво; оптова та роздрібна торгівля; ремонт автотранспортних засобів і мотоциклів; транспорт, складське господарство, поштова та кур'єрська діяльність; фінансова та страхова діяльність; мистецтво, спорт, розваги та відпочинок; надання інших видів послуг.

Згрупуємо ці напрямки у три сектори та ще раз знайдемо коефіцієнти в.ф., але тепер для кожного сектору (див. табл. $2-4$ та рис. $1-3$ ). 
Таблиця 1 - Коефіцієнти виробничої функції кожного напрямку економічної діяльності Київського регіону

\begin{tabular}{|l|l|l|l|}
\hline Коефіціснти ВФ & $\mathbf{a 0}$ & $\mathbf{a 1}$ & $\mathbf{a 2}$ \\
\hline сільське, лісове та рибне господарство & $1 \mathrm{E}+15$ & 0,046 & $-1,81$ \\
\hline промисловість & $\mathbf{3 , 7 7 E - 0 9}$ & $\mathbf{0 , 3 0}$ & $\mathbf{2 , 8 6}$ \\
\hline будівництво & $\mathbf{3 9 7 , 6 7}$ & $\mathbf{0 , 1 0}$ & $\mathbf{0 , 8 6}$ \\
\hline $\begin{array}{l}\text { оптова та роздрібна торгівля; } \\
\text { ремонт автотранспортних засобів і } \\
\text { мотоциклів }\end{array}$ & 524,45 & 0,14 & 0,96 \\
\hline $\begin{array}{l}\text { транспорт, складське господарство, } \\
\text { поштова та кур'срська діяльність }\end{array}$ & $1,13 \mathrm{E}-08$ & 0,053 & 3,22 \\
\hline $\begin{array}{l}\text { тимчасове розміщування й організація } \\
\text { харчування }\end{array}$ & 6580,9 & $-0,014$ & 0,61 \\
\hline інформація та телекомунікації & 199495 & $-0,115$ & 0,27 \\
\hline фінансова та страхова діяльність & 168,27 & 0,059 & 0,944 \\
\hline операції з нерухомим майном & $7 \mathrm{E}+11$ & $-0,146$ & $-1,23$ \\
\hline професійна, наукова та технічна діяльність & $9,0 \mathrm{E}+07$ & $-0,134$ & $-0,32$ \\
\hline $\begin{array}{l}\text { діяльність у сфері адміністративного } \\
\text { та допоміжного обслуговування }\end{array}$ & 2054 & $-0,004$ & 0,73 \\
\hline освіта & $2 \mathrm{E}+67$ & $-0,107$ & $-13,19$ \\
\hline $\begin{array}{l}\text { охорона здоров'я та надання соціальної } \\
\text { допомоги }\end{array}$ & $3 \mathrm{E}+22$ & $-0,067$ & $-3,70$ \\
\hline мистецтво, спорт, розваги та відпочинок & 0,054 & 0,283 & 1,229 \\
\hline надання інших видів послуг & $2,44 \mathrm{E}-07$ & 0,285 & 3,140 \\
\hline
\end{tabular}

Таблиця 2 - Коефіцієнти виробничої функції Сектору 0

\begin{tabular}{|c|c|c|c|c|c|c|c|c|c|}
\hline Рік & $\begin{array}{l}\text { Випуск Y } \\
\text { (тис. грн.) }\end{array}$ & $\begin{array}{l}\text { Капітал K } \\
\text { (тис. грн.) }\end{array}$ & $\begin{array}{l}\text { Кіл-ть } \\
\text { прац. }\end{array}$ & 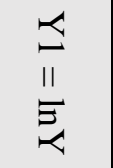 & $\begin{array}{l}\underset{U}{\|} \\
\text { II } \\
\Xi \\
\mathbb{X}\end{array}$ & $\begin{array}{l}\underset{X}{N} \\
\text { II } \\
\Xi \\
ت\end{array}$ & $\begin{array}{c}\mathrm{Y} \\
\text { розрах. }\end{array}$ & & \\
\hline 2010 & $4,09 \mathrm{E}+07$ & $2,57 \mathrm{E}+06$ & 88607 & 17,53 & 14,76 & 11,39 & $4,41 \mathrm{E}+07$ & $\mathbf{a} 2$ & 2,86 \\
\hline 2011 & $5,07 \mathrm{E}+07$ & $2,25 \mathrm{E}+06$ & 91687 & 17,74 & 14,63 & 11,43 & $4,68 \mathrm{E}+07$ & a1 & 0,30 \\
\hline 2012 & $5,86 \mathrm{E}+07$ & $6,18 \mathrm{E}+06$ & 90019 & 17,89 & 15,64 & 11,41 & $6,00 \mathrm{E}+07$ & a0 & $-19,40$ \\
\hline 2013 & $6,69 \mathrm{E}+07$ & 7,77E+06 & 88435 & 18,02 & 15,87 & 11,39 & $6,11 \mathrm{E}+07$ & a0 & $3,8 \mathrm{E}-09$ \\
\hline 2014 & $5,55 \mathrm{E}+07$ & $7,12 \mathrm{E}+06$ & 89219 & 17,83 & 15,78 & 11,40 & $6,11 \mathrm{E}+07$ & & \\
\hline 2015 & $4,88 \mathrm{E}+07$ & $5,07 \mathrm{E}+06$ & 86284 & 17,70 & 15,44 & 11,37 & $5,01 \mathrm{E}+07$ & & \\
\hline 2016 & $5,36 \mathrm{E}+07$ & $6,49 \mathrm{E}+06$ & 84624 & 17,80 & 15,69 & 11,35 & $5,10 \mathrm{E}+07$ & & \\
\hline
\end{tabular}




\section{Сектор 0}

80000000

60000000

40000000

20000000

0

2010

2011

2012

2013

2014

2015

2016

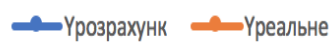

Рисунок 1 - Графіки дійсного випуску та за виробничою функцією Сектору 0

Таблиця 3 - Коефіцієнти виробничої функції Сектору 1

\begin{tabular}{|c|c|c|c|c|c|c|c|c|c|}
\hline Рік & $\begin{array}{l}\text { Випуск Y } \\
\text { (тис. грн.) }\end{array}$ & $\begin{array}{l}\text { Капітал К } \\
\text { (тис. грн.) }\end{array}$ & $\begin{array}{c}\text { Кіл-ть } \\
\text { прац. }\end{array}$ & 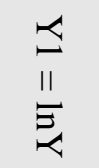 & $\begin{array}{l}\underset{\Delta}{\|} \\
\stackrel{\prime \prime}{\Xi} \\
\underset{\pi}{*}\end{array}$ & $\begin{array}{l}\underset{N}{X} \\
\text { II } \\
\Xi \\
F\end{array}$ & $\begin{array}{c}\mathrm{Y} \\
\text { poзpax. }\end{array}$ & & \\
\hline 2010 & $1,45 \mathrm{E}+07$ & $2,67 \mathrm{E}+06$ & 52677 & 16,49 & 14,80 & 10,87 & $1,52 \mathrm{E}+07$ & $\mathbf{a} 2$ & 0,86 \\
\hline 2011 & $1,93 \mathrm{E}+07$ & $3,98 \mathrm{E}+06$ & 52833 & 16,77 & 15,20 & 10,87 & $1,73 \mathrm{E}+07$ & a1 & 0,10 \\
\hline 2012 & $2,18 \mathrm{E}+07$ & $6,66 \mathrm{E}+06$ & 54459 & 16,90 & 15,71 & 10,91 & $2,14 \mathrm{E}+07$ & a0 & 5,98 \\
\hline 2013 & $1,74 \mathrm{E}+07$ & $5,63 \mathrm{E}+06$ & 50527 & 16,67 & 15,54 & 10,83 & $1,80 \mathrm{E}+07$ & a0 & 397,67 \\
\hline 2014 & $1,34 \mathrm{E}+07$ & $4,06 \mathrm{E}+06$ & 46854 & 16,41 & 15,22 & 10,75 & $1,45 \mathrm{E}+07$ & & \\
\hline 2015 & $1,10 \mathrm{E}+07$ & $3,01 \mathrm{E}+06$ & 40327 & 16,21 & 14,92 & 10,60 & $1,04 \mathrm{E}+07$ & & \\
\hline 2016 & $1,19 \mathrm{E}+07$ & $3,70 \mathrm{E}+06$ & 42592 & 16,30 & 15,12 & 10,66 & $1,21 \mathrm{E}+07$ & & \\
\hline
\end{tabular}

Сектор 1

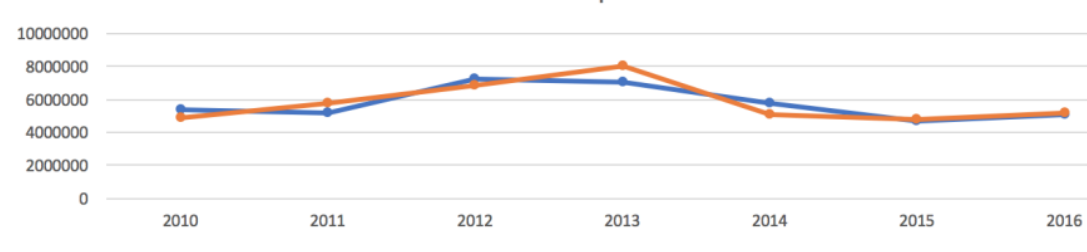

—үрозрахункк —үреальне

Рисунок 2 - Графіки дійсного випуску та за виробничою функцією Сектору 1 
Таблиця 4 - Коефіцієнти виробничої функції Сектору 2

\begin{tabular}{|c|c|c|c|c|c|c|c|c|c|}
\hline Рік & $\begin{array}{l}\text { Випуск Y } \\
\text { (тис. грн.) }\end{array}$ & $\begin{array}{l}\text { Капітал К } \\
\text { (тис. грн.) }\end{array}$ & $\begin{array}{c}\text { Кіл-ть } \\
\text { прац. }\end{array}$ & $\begin{array}{l}\underset{\precsim}{\beth} \\
\underset{\prec}{\Xi}\end{array}$ & 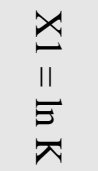 & $\begin{array}{l}x \\
\text { II } \\
\text { II } \\
\Xi \\
V\end{array}$ & $\begin{array}{c}\text { Y } \\
\text { розрах. }\end{array}$ & & \\
\hline 2010 & $8,80 \mathrm{E}+05$ & $3,04 \mathrm{E}+05$ & 46045 & 13,69 & 12,63 & 10,74 & $1,24 \mathrm{E}+06$ & $\mathbf{a} 2$ & 2,11 \\
\hline 2011 & $1,13 \mathrm{E}+06$ & $1,77 \mathrm{E}+06$ & 46787 & 13,94 & 14,39 & 10,75 & $1,11 \mathrm{E}+06$ & a1 & 0,09 \\
\hline 2012 & $1,25 \mathrm{E}+06$ & $7,43 \mathrm{E}+04$ & 46191 & 14,04 & 11,22 & 10,74 & $1,31 \mathrm{E}+06$ & a0’ & $-7,84$ \\
\hline 2013 & $1,38 \mathrm{E}+06$ & $2,34 \mathrm{E}+05$ & 41677 & 14,13 & 12,36 & 10,64 & $1,48 \mathrm{E}+06$ & a0 & 0,0004 \\
\hline 2014 & $1,57 \mathrm{E}+06$ & $1,75 \mathrm{E}+05$ & 44778 & 14,26 & 12,07 & 10,71 & $1,33 \mathrm{E}+06$ & & \\
\hline 2015 & $1,37 \mathrm{E}+06$ & $1,49 \mathrm{E}+05$ & 44561 & 14,13 & 11,91 & 10,70 & $1,35 \mathrm{E}+06$ & & \\
\hline 2016 & $1,61 \mathrm{E}+06$ & $2,99 \mathrm{E}+05$ & 45701 & 14,29 & 12,61 & 10,73 & $1,25 \mathrm{E}+06$ & & \\
\hline
\end{tabular}

Сектор 2

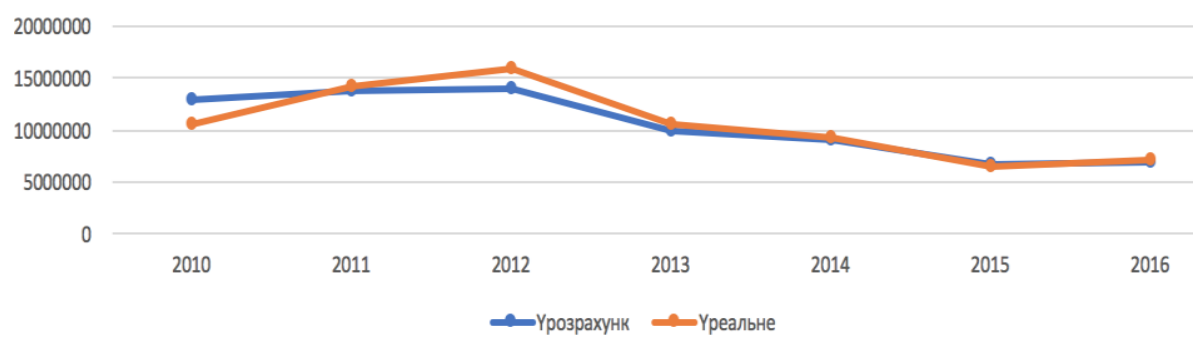

Рисунок 3 - Графіки дійсного випуску та за виробничою функцією Сектору 2

Тепер перейдемо до моделі технологічного переозброєння. Єдиною на даний час економіко-математичною є модель переозброєння трисекторної економіки Колемаєва В.А. [5]. В цій моделі під технологічним переозброєнням автор розуміє зміну в.ф. на більш ефективні $F_{i}^{*}\left(K_{i}, L_{i}\right)>F_{i}\left(K_{i}, L_{i}\right), i=0,1,2$. При побудові такої моделі будемо виходити з таких припущень:

1. Економіка знаходиться в стаціонарному стані. Це характеризується сталістю фондоозброєності і питомих випусків секторів:

$$
k_{i}=\text { const } ; x_{i}=\text { const } ; i=0,1,2
$$

2. Створення нового виробничого процесу відбувається з лагом $\tau$;

3. Оскільки створення виробничого процесу здійснюється за рахунок старого, тобто шляхом використання фіксованих потужностей фондоутворюючого сектору $X_{i}$ і переливання інвестиційних ресурсів 3 матеріального i споживчого секторів в нові сектори, то $\underline{s_{0}}+s_{1}+\underline{s_{2}}+\widetilde{s_{0}}+\widetilde{s_{1}}+\widetilde{s_{2}}=1$, де $\underline{s_{2}}$ - частка інвестиційних ресурсів, що спрямовуються в старий споживчий сектор для забезпечення питомого випуску предметів споживання на мінімально допустимому 
piвні $c, s_{0}$ - частка інвестиційних ресурсів, що спрямовуються в старий матеріальний сектор, для забезпечення матеріальними ресурсами старих фондоутворюючого i споживчого секторів, $\widetilde{s_{l}}(i=0,1,2)$ - частки інвестиційних ресурсів, що спрямовуються в створення потужностей нового виробничого процесу;

4. Новий виробничий процес відрізняється від старого лише по в.ф, в той час як коефіцієнти зносу i прямих матеріальних витрат залишаються незмінними $\mu_{i}=\mu_{i}^{*} ; a_{i}=a_{i}^{*}$.

В цілому весь процес переозброєння розпадається на три етапи: накопичення, віддача накопичень, прискорене витіснення старого процесу виробництва. На етапі накопичення при $0<t<\tau$ діє тільки старий спосіб виробництва. На етапі віддачі накопичення при $\tau<t<T$ потужності нового способу починають давати віддачу, проте новий технологічний спосіб ще не в змозі забезпечити суспільство предметами споживання хоча б на мінімальному рівні, тому старий і новий способи співіснують при поступовому переливанні трудових ресурсів із старого виробництва в нове. Оскільки на цьому етапі паралельно діють старі і нові потужності, то розподіл інвестиційних ресурсів також здійснюється паралельно: старі ресурси - в старий спосіб з частками $s_{0}, s_{1}, s_{2}, s_{0}+s_{1}+s_{2}=1$; нові ресурси - в новий спосіб 3 частками $s_{0}^{*}, s_{1}^{*}, s_{2}^{*}, s_{0}^{*}+s_{1}^{*}+s_{2}^{*}=1$. При цьому трудові ресурси розподіляються як на старий, так і на новий процес виробництва. Приймемо також, що розподіл трудових ресурсів здійснюється за сталості фондоозброєності (кожного сектора в кожному способі), при цьому всередині кожного способу лаг віддачі капіталовкладень дорівнює нулю. Починаючи з $t=T$ в моделі здійснюється в рамках нового процесу виробництва нормальний відтворювальний процес, який в безперервному часу і відсутності лага капіталовкладень описується наступними рівняннями:

$$
\frac{d K_{i}^{*}}{d t}=-\mu_{i} K_{i}^{*}+s_{i}^{*}(t) X_{1}^{*}(t), \mu_{i}=\text { const }, i=0,1,2 .
$$

Слід зазначити, що в цій моделі капіталоємність $k_{i}^{*}$ для секторів у новому укладі дорівнює старим значенням $\hat{k}_{i}$, а частки трудових ресурсів нового устрою $\theta_{i}^{*}-$ прагнуть до значень часток трудових ресурсів старої економіки $\hat{\theta}_{i}$. Це означає, що при повному переозброєнні економіки, в нас залишиться мінімальна кількість безробітних, або в загалі вона буде дорівнювати 0, тобто під час процесу переозброєння нікого не звільнять. Для дискретизації моделі управління застосуємо метод кінцевих різниць (МКР). Отримана дискретизована модель $є$ задачею нелінійного програмування. Розв'яжемо отриману задачу за допомогою квазіньютонівського методу послідовного квадратичного програмування SLSQP [8]. 
Задача оптимального керування для моделі переозброєння трисекторної економіки буде мати такий вигляд:

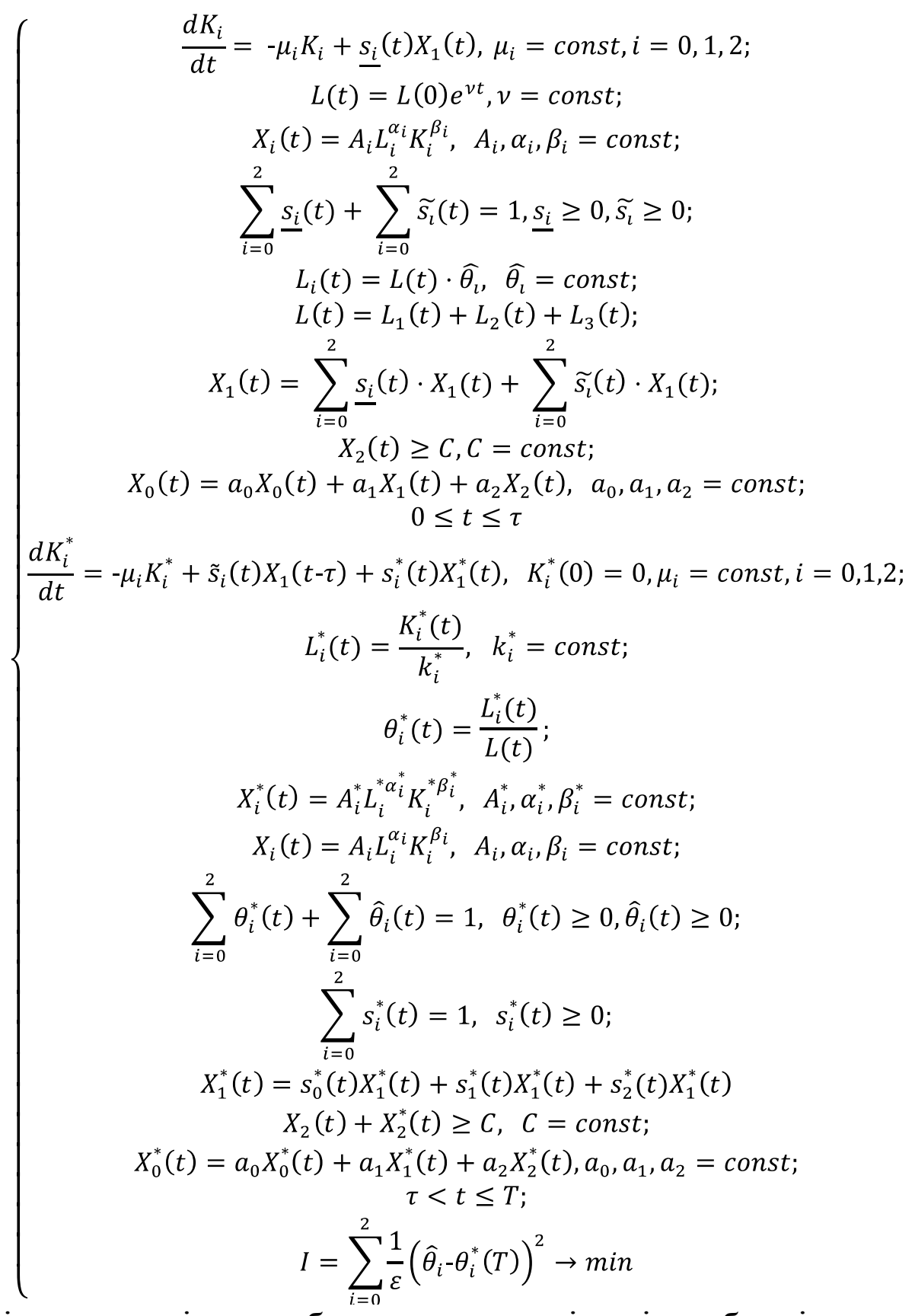

Вхідні данні для моделі переозброєння наведені далі у таблиці. 
Таблиця 5 - Початкові дані для моделі переозброєння

\begin{tabular}{|c|c|c|c|}
\hline & Сектор 0 & Сектор 1 & Сектор 2 \\
\hline $\boldsymbol{a}$ & 0.357 & 1.958 & 1.369 \\
\hline $\boldsymbol{A}$ & $3.76 \mathrm{E}-09$ & 397.67 & 0.00039 \\
\hline $\boldsymbol{\alpha}$ & 2.86 & 0.86 & 2.11 \\
\hline $\boldsymbol{\beta}$ & 0.3 & 0.1 & 0.09 \\
\hline $\boldsymbol{A}^{*}$ & $7.526 \mathrm{E}-09$ & 800 & 0.0008 \\
\hline $\boldsymbol{\alpha}^{*}$ & 2.86 & 0.86 & 2.11 \\
\hline $\boldsymbol{\beta}^{*}$ & 0.3 & 0.1 & 0.09 \\
\hline $\boldsymbol{k}^{*}$ & 58.74 & 283.59 & 3.23 \\
\hline $\boldsymbol{\mu}$ & 0.69 & 0.36 & 0.435 \\
\hline $\boldsymbol{\theta}$ & 0.56 & 0.1 & 0.34 \\
\hline $\boldsymbol{K}$ (тис. грн.) & 6181250.115 & 93712447.62 & 2662889.004 \\
\hline $\boldsymbol{L}$ & 90019 & 16289 & 54514 \\
\hline $\boldsymbol{\nu}$ & \multicolumn{3}{|c|}{$-0,021$} \\
\hline $\boldsymbol{L}_{\mathbf{0}}$ & 6437347.187 \\
\hline $\boldsymbol{C}$ (тис. грн.) & \multicolumn{3}{|c}{} \\
\hline
\end{tabular}

Звернемо увагу на те, що до вхідних даних зроблені такі припущення:

1. Еластичність по капіталу та трудовим ресурсам однакова як для нового, так і для старого процесу виробництва: $\alpha_{i}=\alpha_{i}^{*}, \beta_{i}=\beta_{i}^{*}$;

2. Технічний прогрес у новому процесі виробництва перевищує старий у 2 рази $2 A=A^{*}$;

3. Нижня границя споживання $C$ встановлена на базі мінімального значення, яке було у 2015 в період з 2010 по 2016 у цінах 2010 року;

4. Для виконання умови стаціонарності економіки перед початком переозброєння зроблена разова інвестиція у фондоутворюючий сектор у розмірі 90 млрд. грн;

5. Значення по капітальних інвестиціях та трудових ресурсах було взято за 2012 рік.

Наведемо результати розрахунків. При вирішенні задачі з фіксованими значеннями $(\tau, T)=((1,2) ;(1.5,3) ;(1.5,2) ;(1,3))$ на базі експертних оцінок, процес переозброєння не було завершено повністю. При нефіксованих значеннях $\tau$ та $T$ були отримані мінімальні значення цільової функції, тобто процес переозброєння було повністю завершено, коли $\tau=2$, а $T=4$, з будьяким кроком дискретизації $(\Delta t=1.0 ; 0.5 ; 0.25)$. 


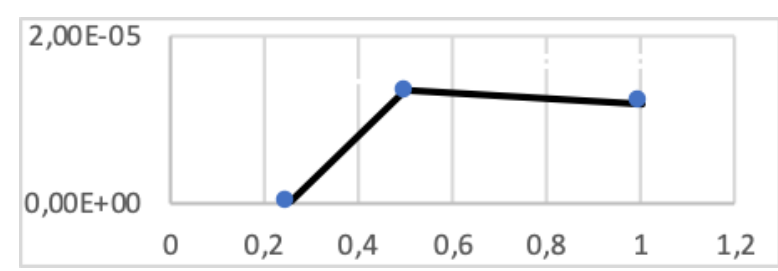

Рисунок 4 - Значення цільової функції в залежності від кроку дискретизації

Як бачимо з рис. 4, розбіжність значень цільової функції між різними кроками дискретизації дуже мала, тобто можемо зробити висновок, що знайдено наближення до мінімального значення.

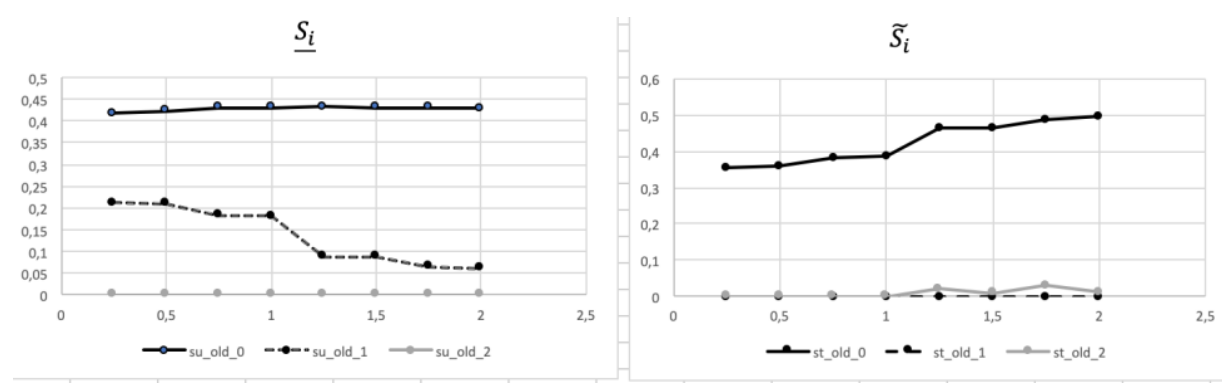

Рисунок 5 - Інвестиційні частки в старий та новий виробничий процеси на першій фазі переозброєння

На рис. 5 наведено поведінку векторів керування, а саме інвестиційні частки для старого та нового виробничих процесів. Загалом протягом всієї першої фази склалася така пропорція: 63\% інвестицій йдуть у старий виробничий процес, а $37 \%$ у новий від загального обсягу інвестицій. Темп зростання добробуту $\sum_{i=0}^{2} K_{i} / \sum_{i=0}^{2} L_{i}$ до початку переозброєння у 2014 році порівняно з 2012 роком дорівнював 94\%.

На рис. 6 бачимо, що поведінка векторів керування значно ускладнилась стосовно зміни інвестиційних часток у новому виробничому процесі, тут акцент інвестицій у споживчій сектор на початку $\left(S_{0}^{*}=0 ; S_{1}^{*}=0,04 ; S_{0}^{*}=0,96 ;\right)$ змістився на фондоутворюючий сектор $\left(S_{0}^{*}=0,01 ; S_{1}^{*}=0,87 ; S_{0}^{*}=0,12\right.$;) наприкінці другої фази. Значно спростилась ситуація у старому виробничому процесі, в ньому зусилля спрямовані на підтримку споживчого сектору. Темп зростання добробуту $\sum_{i=0}^{2} K_{i}^{*} / \sum_{i=0}^{2} L_{i}$ після закінчення переозброєння став дорівнювати $376 \%$. 

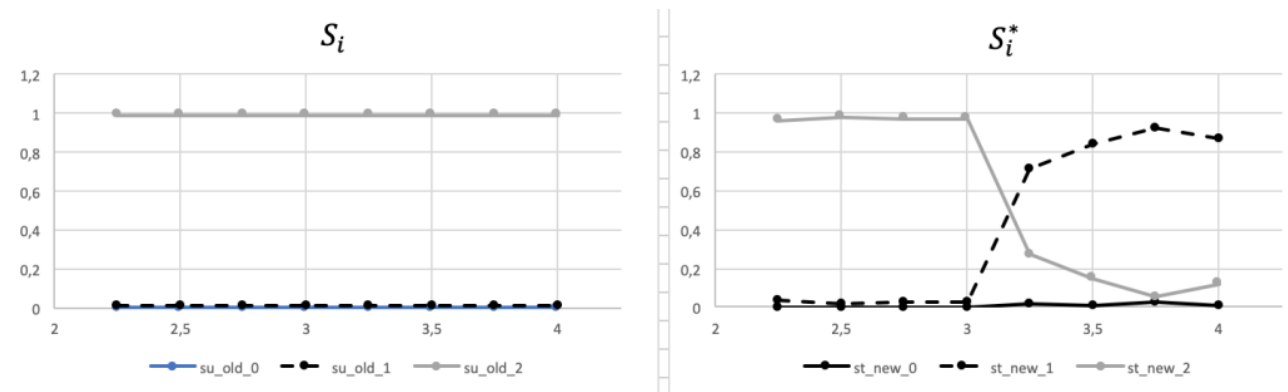

Рисунок 6 - Окремі інвестиційні частки старому та новому виробничих процесах на другій фазі переозброєння

Також для більшої наочності приведемо графік перерозподілу трудових ресурсів.

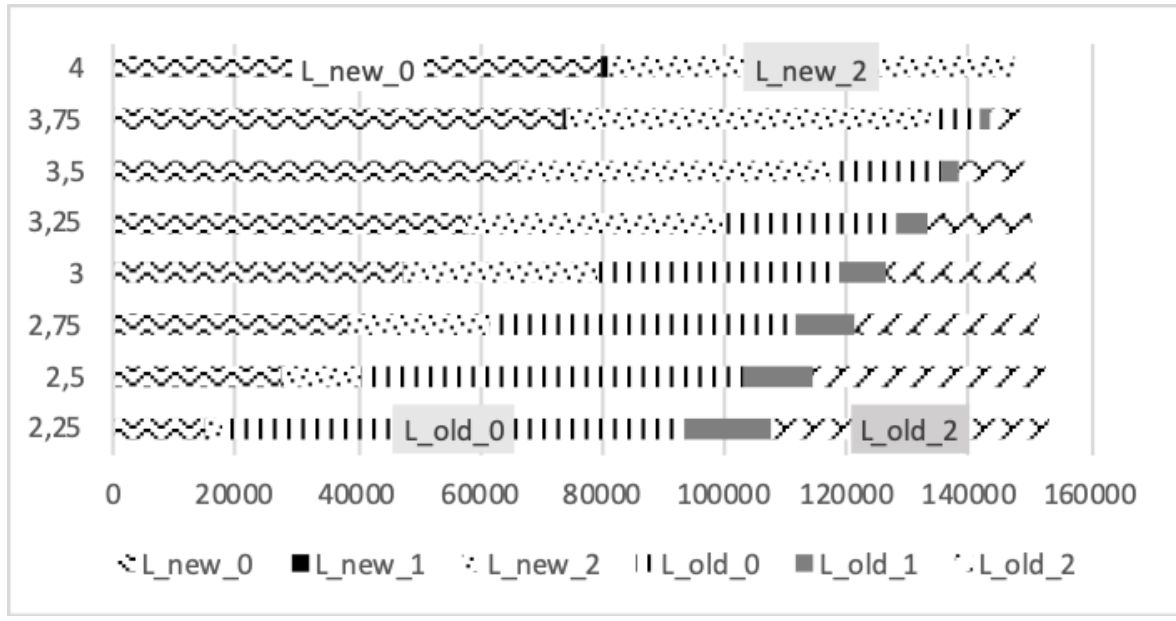

Рисунок 7 - Процес перерозподілу трудових ресурсів зі старого на нове виробництво

3 рис. 7 видно, що перерозподіл трудових ресурсів з нульового та другого секторів відбувався рівномірно протягом всієї другої фази, а перерозподіл трудових ресурсів фондоутворюючого сектору був зроблений на останніх кроках другої фази.

Висновки. У рамках реформи децентралізації в Україні відбувається зміна підходів до регіонального управління та планування усіх видів діяльності. Київська область за допомогою організаційної та методологічної підтримки Європейського Союзу поставила перед собою мету стати одним із лідерів за показниками людського та економічного розвитку. Станом на 2017 рік за індексом людського розвитку регіон посідає 13 місце, а за ВРП четверте. Стратегію соціально-економічного розвитку регіону можливо і необхідно 
вдосконалювати. Одним із варіантів вдосконалення підходу до реалізації операційної цілі по модернізації існуючого виробництва може стати економікоматематична модель 3 переозброєння регіону. В рамках статті було показано можливість застосування такої моделі та результати, які можна отримати, а саме переозброєння більшості напрямків економічної діяльності за 4 роки, оптимально розподіляючи інвестиції між секторами.

Використання моделі переозброєння це новий підхід до розробки ефективної стратегії в управлінні регіональними соціально-економічними процесами. В цьому полягає наукова новизна та практична значимість даного дослідження. Перспективи подальших наукових розробок за даним напрямом це вдосконалення моделі переозброєння з урахуванням специфіки регіону та включення у процес моделювання змінних, які характеризують добробут населення.

\section{Література:}

1. Стратегія розвитку Київської області на період до 2020 року [Електронний ресурс]. Режим доступу: http://oblpto.in.ua/images/docum/nakazi/strateg2020.pdf

2. Звіт про результати реалізації проектів регіонального розвитку, визначених Планом заходів з реалізації у 2015-2017 роках Стратегії розвитку Київської області на період до 2020 року за 2017 рік [Електронний ресурс]. - Режим доступу: https://docs.wixstatic.com/ugd/d9f7ba_9a44b85b2e4446c087c1925555e80dc0.pdf

3. Державна служба статистики України. [Електронний ресурс]. - Режим доступу: http://www.ukrstat.gov.ua/

4. Головне управління статистики у Київській області [Електронний ресурс]. - Режим доступу: http://kyivobl.ukrstat.gov.ua/

5. Колемаев В.А. Математическая экономика: учебник для вузов. М.: ЮНИТИ-ДАНА, 2005. $399 \mathrm{c}$.

6. Грабовецький Б.С. Виробничі функції в економічних дослідженнях. Вісник СумДУ. Серія Економіка. 2013. № 1. С. 60-68.

7. Гуменюк В.Я. Переваги та недоліки застосування функції Кобба-Дугласа як інструменту управління виробничими ресурсами транспортних підприємств. Вісник Національного університету "Львівська політехніка". Проблеми економіки та управління. 2000. № 391. C. $157-162$.

8. Kraft D. A software package for sequential quadratic programming. Forschungsbericht: Deutsche Forschungs- und Versuchsanstalt fur Luft- und Raumfahrt.1988, 33 p. 